\title{
MOLECULAR CHARACTERIZATION OF ENDANGERED MEDICINAL PLANT SPECIES HEDYCHIUM CORONARIUM FROM EASTERN INDIA
}

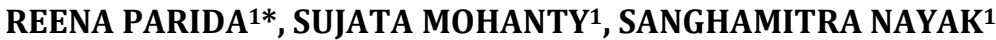 \\ Centre of Biotechnology, Siksha 0 Anusandhan University, Kalinga Nagar, Ghatikia, Bhubaneswar-751003, Odisha, India \\ Email: ms.reenas@gmail.com
}

Received: 01 Jul 2016 Revised and Accepted: 18 Nov 2016

\section{ABSTRACT}

Objective: Molecular characterization of Hedychium coronarium from 4 different populations of Odisha using 9 inter simple sequence repeats and 15 random amplified polymorphic DNA markers to indicate the closeness of species and hybrids quickly and efficiently.

Methods: A dendrogram was constructed through sequential agglomerative hierarchial and nested (SAHN) clustering and un-weighted pair group method with arithmetic mean (UPGMA) analysis using Jaccard's similarity coefficient of combined markers using this particular species.

Results: Two major clusters were found, i.e., cluster-I (Malkangiri-1, Phulabani-1, Phulabani-3, Malkangiri-2, Khurda-1, Khurda-2, Khurda-3, Angul3, Angul-1, Angul-2 and Phulabani-2) and cluster-II (Malkangiri-3). The clustering pattern also revealed moreover the extent of genetic similarity between germplasms collected from four different regions population.

Conclusion: The potential of this technique would be further realised to the fullest extent for the identification and tagging of the important novel gene in different taxa, unexplored yet, thus facilitating the improvement of desired taxa of Zingiberaceae. The findings would be of immense enough significance for complementing the strategies of conservation and characterization of these important taxa of Zingiberaceae following modern biotechnological approach.

Keywords: Hedychium coronarium, ISSR, RAPD, Molecular characterization.

(C) 2017 The Authors. Published by Innovare Academic Sciences Pvt Ltd. This is an open access article under the CC BY license (http://creativecommons.org/licenses/by/4. 0/) DOI: http://dx.doi.org/10.22159/ijpps.2017v9i1.13815

\section{INTRODUCTION}

There are several molecular markers which have been regularly used for studying genetic relations, population genetics and genetic characterization in different plant groups and crop cultivars. The molecular markers are not influenced by the external environmental factors unlike that of morphological markers hence accurately testify genetic relationship between and among plant groups. Also for proper conservation programme characterization of plants genetically is necessary. These are now routinely used as because it is more reliable, less time consuming and easy to handle in comparison with morphological and biochemical markers. It helps to indicate the closeness of species and hybrids quickly and efficiently [1]. Now days, number of molecular markers (random amplified polymorphic DNA (RAPD), restriction fragment length polymorphism (RFLP), inter-simple sequence, repeats (ISSR), simple sequence repeats (SSR), isozymes, proteins, etc.) are being widely used for germplasm evaluation, measuring genetic diversity, genetic mapping, for assessing genetic relationship among different taxa and for the detection of genetic changes caused due to mutation or genetic engineering. RAPD have been used for measuring genetic diversity in several plant species like apple [2], wheat [3], Piper [4], Triticum [5], Gossypium [6], Oryza [7], Barley [8], Sugarcane [9], Cymbopogon [10], Tea [11], Soybean [12], Banana [13], Broccoli [14]. DNA markers are widely used in genome mapping in a wide range of plant species and are now being increasingly employed for studies of genetic relationship among species and within accessions $[15,16]$. RAPD and AFLP (amplified fragment length polymorphism) markers have the potential to reveal a large amount of variation with good coverage of entire genome $[17,18]$. There are many reports available on genetic and chromatographic fingerprinting of medicinal and aromatic plants for identification [19-23]. Some reported ISSR as a valuable tool for genetic diversity analysis in spices [24]. The competence of ISSR in clonal fidelity assessment on Allium and Aloe was established successfully [25]. The genetic fidelity of vanilla using RAPD and ISSR primers [26]. More recently [27] used RAPD and ISSR markers in vanilla to assess the genetic diversity and [28] used ISSR marker to determine the level of genetic diversity and relatedness among strawberry cultivars. Previously there was no report about the molecular characterization of Hedychium coronarium from eastern India. This molecular technique could be used in the study of genetic diversity of endangered plant species to conserve the particular species.

\section{MATERIALS AND METHODS}

Plant material

In the present investigation, Hedychium coronation was collected from the different wild areas of Odisha like Malkangiri, Phulabani, Khurda and Angul districts. After collection, the rhizomes of these medicinal plant samples were grown in the medicinal plant garden of Center of Biotechnology, Siksha 0 Anusandhan University, Bhubaneswar, Odisha.

\section{Isolation of genomic DNA}

Genomic DNA was isolated by following the protocol of [29] with little modification. Two grams of fresh, young leaf samples was grinded with $2 \%$ insoluble PVPP to make a fine powder in a cold mortar and pestle with repeated addition of liquid nitrogen. Thawing was avoided to reduce the shearing of DNA. The powder was then transferred to a $50 \mathrm{ml}$ centrifuge tube containing $10 \mathrm{ml}$ of pre-warmed $\left(60^{\circ} \mathrm{C}\right) 2 \%$ CTAB-DNA extraction buffer $(10 \%$ CTAB; $4 \mathrm{M} \mathrm{NaCl} ; 0.5 \mathrm{M}$ EDTA, $\mathrm{pH} 8 ; 1 \mathrm{M}$ Tris- $\mathrm{HCl}, \mathrm{pH} 8 ; 2 \% \quad \beta$ mercaptoethanol) and was mixed vigorously. The mixture was incubated in a water bath (YSI412, Yorco universal) for one hour at $65^{\circ} \mathrm{C}$ with intermittent gentle shaking. After incubation, the mixture was cooled to room temperature and emulsified with an equal volume of phenol: chloroform: isoamyl alcohol (25:24:1) and was gently mixed. Then, it was centrifuged at $10,000 \mathrm{rpm}$ for $20 \mathrm{~min}$ in a cooling centrifuge (C-24BL, Remi) at room temperature. The upper aqueous phase was pipetted out with the help of a micropipette into another $50 \mathrm{ml}$ centrifuge tube and mixed with 2.5 volume of prechilled dehydrated ethanol. After quick inversion, DNA, like a mass 
of cotton threads was precipitated. The precipitated nucleic acid was spooled out with a bend glass Pasteur pipette, washed twice with $70 \%$ ethanol, stored in a $1.5 \mathrm{ml}$ microcentrifuge tube and dried. The dried DNA was dissolved in an excess amount of $\mathrm{T}_{10} \mathrm{E}_{1}$ buffer (TrisCl 10 mmol, EDTA 1 mmol with $\mathrm{pH}$ 8).

\section{Purification of genomic DNA}

The dissolved DNA was impure with proteins, RNA and phenolic in some cases so the crude DNA was purified and RNA was removed. The RNA was removed by giving RNase treatment. For $1 \mathrm{ml}$ of crude DNA solution, $60 \mu \mathrm{g}$ of RNase A was added, and the solution was incubated with continuous shaking in a water bath at $37^{\circ} \mathrm{C}$ for $1 \mathrm{hr}$. After one hour it was removed from the water bath and an equal volume of phenol: chloroform: isoamyl alcohol (25:24:1) was added and gently mixed thoroughly. The solution was then centrifuged in cooling centrifuge at $10,000 \mathrm{rpm}$ for $20 \mathrm{~min}$ at $20^{\circ} \mathrm{C}$ and the upper aqueous phase was pipetted out. It was again washed with chloroform: isoamyl alcohol (24:1) twice and centrifuged at 10,000 rpm for $20 \mathrm{~min}$ at room temperature. The upper aqueous phase was separated after centrifugation (as described earlier) and mixed with $1 / 10^{\text {th }}$ volume of $3 \mathrm{M}$ sodium acetate $(\mathrm{pH} 4.8)$. DNA was precipitated by adding 2.5 volume of chilled absolute ethanol and pelleted by spinning. The pellet was washed twice with $70 \%$ ethanol, carefully and dried under vacuum. The dried DNA was dissolved in minimum amount of $\mathrm{T}_{10} \mathrm{E}_{1}$ buffer ( $\left.\mathrm{pH} 8\right)$.

\section{Test for quality and quantity of the purified DNA}

The quality and quantity of DNA were measured by UV-vis spectrophotometer (Model evolution 220, Thermo Fisher Scientific,). The total DNA quantity was measured by taking the absorbance at $260 \mathrm{~nm}$ wavelength and the quality of the DNA was confirmed from the absorbance ratio at $260 \mathrm{~nm}$ and $280 \mathrm{~nm}$. It was reported that if the ratio is about 1.8 to 2.0 then the quality of the DNA is good [30]. For final checking the quality as well as the quantity of DNA, the DNA was loaded in $0.8 \%$ agarose gel alongside diluted uncut lambda DNA as standard and electrophoresed. It was observed that the DNA from all the samples was very good in quality. After quantification, the DNA was diluted with $\mathrm{T}_{10} \mathrm{E}_{1}$ buffer to a working concentration of $25-\mathrm{ng} / \mu \mathrm{l}$ for RAPD and ISSR analysis.

\section{RAPD analysis}

Two types of polymerase chain reaction (PCR) based molecular techniques namely RAPD and ISSR were utilised for the present study.

For RAPD analysis random decamer operon primers were dissolved in double sterilised $\mathrm{T}_{10} \mathrm{E}_{1}$ buffer, $\mathrm{pH} 8.0$ to the working concentration of $15 \mathrm{ng} / \mu \mathrm{l}$. Few selected primers as per the reproducibility and amplification pattern from $\mathrm{A}, \mathrm{C}, \mathrm{D}, \mathrm{N}$ and $\mathrm{AF}$ series OPA04, OPA07, OPA09, OPA18, OPC02, OPC05, OPC011, OPD03, OPD07, OPD08, OPD12, OPD18, OPD20, OPN04, OPN16, OPN18, AF5, AF14 and AF15, etc. were used for RAPD analysis. The RAPD analysis was performed as per the methodology described by [31]. Each amplification reaction mixture of $25 \mu \mathrm{l}$ volume contained $2.5 \mu \mathrm{l}$ of $10 \mathrm{X}$ assay buffer $(100 \mathrm{mmol}$ Tris- $\mathrm{HCl}, \mathrm{pH} 8.3,500 \mathrm{mmol} \mathrm{KCl}$, $1.5 \mathrm{mmol} \mathrm{MgCl}_{2}$ and $0.1 \%$ gelatin), $200 \mu \mathrm{M}$ of each dNTPs (dATP, dCTP, dGTP and dTTP), 15 ng of primer, 0.5 unit of Taq DNA polymerase and $25 \mathrm{ng}$ of template DNA. The amplification reaction was carried out in PCR (Gene amp PCR system 9700, Applied Biosystems). The amplification was performed in three steps PCR. The initial denaturation of the template DNA was carried out at 94 ${ }^{\circ} \mathrm{C}$ for $5 \mathrm{~min}$ for one cycle. The second step was carried out for 42 cycles and each cycle consisting of three temperature steps, i.e., one minute at $92{ }^{\circ} \mathrm{C}$ for denaturation of the template, one minute at $37^{\circ} \mathrm{C}$ for primer annealing followed by two minutes at $72{ }^{\circ} \mathrm{C}$ for primer extension. The final step consisted of only one cycle i.e. $7 \mathrm{~min}$ at 72 ${ }^{\circ} \mathrm{C}$ for complete polymerization. The soaking temperature was $4{ }^{\circ} \mathrm{C}$. After the completion of the PCR $2.5 \mu \mathrm{l}$ of $6 \mathrm{X}$ loading dye was added to the amplified products and was stored at $-20^{\circ} \mathrm{C}$ till further use.

\section{ISSR analysis}

Nine numbers of ISSR primers were used for ISSR analysis. Those primers were namely $(\mathrm{GAC})_{5},(\mathrm{GTGC})_{4},(\mathrm{GACA})_{4},(\mathrm{AGG})_{6},(\mathrm{GA})_{9} \mathrm{~T}$, $\mathrm{T}(\mathrm{GA})_{9},(\mathrm{GTG})_{5},(\mathrm{GGA})_{4}$ and $(\mathrm{CAA})_{5}$. The ISSR analysis was performed as per the methodology is given by [32]. Each amplification reaction mixture of $25 \mu$ contained $25 \mathrm{ng}$ of template DNA, $2.5 \mu \mathrm{l}$ of $10 \mathrm{X}$ assay buffer $(100 \mathrm{mmol}$ Tris- $\mathrm{HCl} \mathrm{pH} \mathrm{8.3,500}$ $\mathrm{mmol} \mathrm{KCl}, 1.5 \mathrm{mmol} \mathrm{MgCl}_{2}$ and $0.1 \%$ gelatin), $200 \mu \mathrm{M}$ each of dNTPs (dATP, dCTP, dGTP and dTTP), 44 ng of primer and 0.5 unit Taq DNA polymerase. The amplification was carried out in a thermal cycler. The first cycle consisted of denaturation of template DNA at $94{ }^{\circ} \mathrm{C}$ for $5 \mathrm{~min}$, primer annealing at a specific temperature for a particular primer for 1 minute and primer extension at $72{ }^{\circ} \mathrm{C}$ for $2 \mathrm{~min}$. In the subsequent 42 cycles, the period of denaturation was reduced to 1 minute while the primer annealing and primer extension time were maintained same as in the first cycle. The last cycle consisted of only primer extension at $72{ }^{\circ} \mathrm{C}$ for $7 \mathrm{~min}$ and then the amplified products were resolved in $2 \%$ agarose gel stained with ethidium bromide.

\section{Agarose gel electrophoresis}

The PCR products for RAPD were separated in $1.5 \%$ agarose gel while those of the ISSR products were resolved in $2 \%$ agarose gel. The agarose gel was prepared with TAE buffer ( $40 \mathrm{mmol}$ Tris base, $20 \mathrm{mmol}$ sodium acetate, $20 \mathrm{mmol}$ EDTA, glacial acetic acid; $\mathrm{pH} 7.2$ ), $125 \mathrm{ml}$ 1X TAE buffer was taken in a $500 \mathrm{ml}$ conical flask and 1.875 gm of agarose was added, boiled for complete melting of agarose and then cooled to $50{ }^{\circ} \mathrm{C}$. After cooling, $6.25 \mu \mathrm{l}$ of ethidium bromide solution $(10 \mathrm{mg} / \mathrm{ml})$ was added, mixed properly and the gel solution was poured on the gel casting tray and left for one hour for complete gelling. Then the gel was submerged in a gel tank (1704495 Sub-Cell Model, Bio-Rad) containing $1 \mathrm{X}$ TAE buffer. Prior to loading the samples, the comb was removed. In the submerged gel $27 \mu \mathrm{l}$ of the PCR amplified samples containing the tracking dye were loaded in each well. Standard DNA ladder (Gene Ruler $100 \mathrm{bp}$ ) was loaded in the first well after the amplified samples were loaded in other wells to know the size of the amplified DNA fragment. The electrophoresis was performed at 60 volts for $3 \mathrm{~h}$.

After electrophoresis, the gel was visualised under the UV-trans illuminator (0507, BioRad) and photographed using gel documenting system (76S/07634, Universal Hood II Bio-Rad) for scoring the bands. The sizes of the amplicons were determined by comparing them with that of the ladder. The entire process was repeated at least twice to confirm the reproducibility.

\section{Scoring of the data}

The data was scored as ' 1 ' for the presence and ' 0 ' for the absence of the band for each primer genotype combination for RAPD and ISSR analysis. All the bands were considered underestimation of the genetic similarity [33].

\section{Statistical analysis of the data}

\section{Resolving power (Rp)}

Resolving power of the RAPD and ISSR were calculated as per [34]. Resolving power is: $\mathrm{Rp}=\Sigma \mathrm{IB}$ (IB (Band informative-ness) $=1$ $[2 \times(0.5-\mathrm{P})], \mathrm{P}$ is the proportion of the species containing the band.

\section{Primer index (PI)}

The primer index was calculated from the polymorphic index. A polymorphic index (PIC) was calculated as $\mathrm{PIC}=1-\sum P^{2}, P_{i}$ is the band frequency of the $i$ th allele [35]. In the case of RAPDs and ISSRs, the PIC was considered to be $1-p^{2}-q^{2}$, where $p$ is band frequency and $\mathrm{q}$ is no band frequency [36]. The PIC value was then used to calculate the primer index (PI). PI is the sum of the PIC of all the markers amplified by the same primer.

\section{Jaccard's similarity}

Jaccard's coefficient of similarity [37] was measured and a phylogram based on similarity coefficients was generated by unweighted pair group method using arithmetic averages (UPGMA) [38] and the SAHN clustering was obtained. The entire analysis was performed using the statistical package NTSYS-pc 2.02e [39].

\section{Bootstrapping}

In addition to the classical resampling methods the statistical testing of robustness of the obtained trees, such as bootstrapping was 
implemented. This test has been created to give a possibility of having more distances with the same values. In such case, the order of taxa influences the result of the tree building. Rearrangement of taxa could reveal this situation

\section{Chemicals and reagents:}

RNase A (Qiagen Inc., USA)

Agarose (SRL Pvt. Ltd, India)

RAPD operon primers (Operon Tech., Alameda, USA)

dNTP (MBI Fermentas, Lithuania)

Taq DNA polymerase (Bangalore Genei Pvt. Ltd, Bangalore, India)

6X loading dye (MBI Fermentas, Lithuania)

ISSR primers (Bangalore Genei Pvt. Ltd, Bangalore, India)

DNA ladder (MBI Fermentas, Lithuania)

\section{RESULTS}

\section{Genomic DNA isolation and quantification}

The modified CTAB protocol yielded a good quality of DNA as revealed by agarose gel electrophoresis. The concentration of DNA varied from 100-350 $\mathrm{ng} / \mu \mathrm{l}$.

\section{RAPD analysis}

Out of 25 random decamer oligonucleotide primers, 15 primers were used for the present work basing upon their amplification and clarity of banding pattern. All the 4 populations of $H$. coronarium (Malkangiri, Phulabani, Khurda, Angul), each in triplicates, were used which produced distinct, reproducible amplicons (fig. 1a, b). A total of 62 bands were amplified all of which were found to be monomorphic in nature. The highest number of bands (7) were amplified with primer OPD20 (450-3000bp), and lowest number of the band (2) was amplified with primer OPA18 (1850-2000bp). No unique bands were found with all the primers. An average number of bands per primer was found to be 4.1. The resolving power of the primers was varied from 4-14 where the primer with maximum resolution power was OPD20 (14) and the primer with minimum resolution power was OPA18 (4) (table 1).

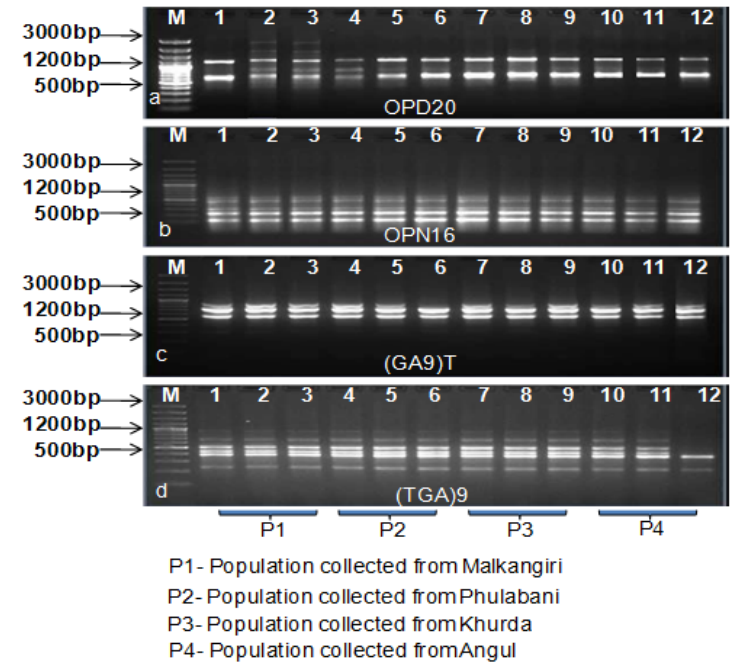

Fig. 1(a, b) RAPD banding pattern (c, d) ISSR banding pattern of Hedychium corornarium from different populations (Lane 1-12) and M-marker

Table 1: Details of RAPD, ISSR and combined marker analysis as revealed among 4 populations of Hedychium corornarium

\begin{tabular}{|c|c|c|c|c|c|c|c|c|}
\hline \multirow[t]{2}{*}{ Markers } & Primer & $\begin{array}{l}\text { Sequence of } \\
\text { Oligonucleotides }\end{array}$ & $\begin{array}{l}\text { Approx } \\
\text { fragment } \\
\text { Size(bp) }\end{array}$ & $\begin{array}{l}\text { Total } \\
\text { bands }\end{array}$ & $\begin{array}{l}\text { Monomorphic } \\
\text { bands }\end{array}$ & $\begin{array}{l}\text { Polymorphic } \\
\text { bands }\end{array}$ & $\begin{array}{l}\text { Unique } \\
\text { bands }\end{array}$ & $\begin{array}{l}\text { Resolving } \\
\text { power }\end{array}$ \\
\hline & OPA4 & 5'AATCGGGCTG3' & $600-1400$ & 5 & 5 & 0 & 0 & 10 \\
\hline \multirow[t]{14}{*}{ RAPD } & OPA7 & 5'GAAACGGGTG3' & $400-2200$ & 4 & 4 & 0 & 0 & 8 \\
\hline & OPA8 & 5'AGGTGACCGT3' & $750-1350$ & 4 & 4 & 0 & 0 & 8 \\
\hline & OPA18 & 5'AGGTGACCGT3' & $1850-2000$ & 2 & 2 & 0 & 0 & 4 \\
\hline & OPC2 & 5'GTGAGGCGTC3' & $600-1300$ & 3 & 3 & 0 & 0 & 6 \\
\hline & OPC5 & 5'GATGACCGCC3' & $900-2000$ & 5 & 5 & 0 & 0 & 10 \\
\hline & OPC11 & 5'AAAGCTGCGG3' & $600-1500$ & 5 & 5 & 0 & 0 & 10 \\
\hline & OPD3 & 5'GTCGCCGTCA3' & $1031-1600$ & 3 & 3 & 0 & 0 & 6 \\
\hline & OPD7 & 5'TTGGCACGGG3' & $400-2000$ & 4 & 4 & 0 & 0 & 8 \\
\hline & OPD8 & 5'GTGTGCCCCA3' & $900-1800$ & 4 & 4 & 0 & 0 & 8 \\
\hline & OPD18 & 5'GAGAGCCAAC3' & $225-1500$ & 3 & 3 & 0 & 0 & 6 \\
\hline & OPD20 & 5'ACCCGGTCAC3' & $450-3000$ & 7 & 7 & 0 & 0 & 14 \\
\hline & OPN4 & 5'GACCGACCCA3' & $500-1650$ & 5 & 5 & 0 & 0 & 10 \\
\hline & OPN16 & 5'AAGCGACCTG3' & $250-400$ & 4 & 4 & 0 & 0 & 8 \\
\hline & OPN18 & 5'GGTGAGGTCA3' & $450-1400$ & 4 & 4 & 0 & 0 & 8 \\
\hline Total & & & & 62 & 62 & $\mathbf{0}$ & $\mathbf{0}$ & \\
\hline \multirow[t]{9}{*}{ ISSR } & SPS1 & $(\mathrm{GAC}) 5$ & $280-250$ & 13 & 13 & 0 & 0 & 26 \\
\hline & SPS2 & (GTGC) 4 & $325-000$ & 8 & 8 & 0 & 0 & 16 \\
\hline & SPS3 & $(\mathrm{GACA}) 4$ & $325-1350$ & 10 & 6 & 4 & 2 & 15 \\
\hline & SPS4 & $(\mathrm{AGG}) 6$ & $275-825$ & 9 & 9 & 0 & 0 & 18 \\
\hline & SPS5 & (GA)9T & $300-850$ & 10 & 10 & 0 & 0 & 20 \\
\hline & SPS6 & $\mathrm{T}(\mathrm{GA}) 9$ & $225-950$ & 6 & 6 & 0 & 0 & 12 \\
\hline & SPS7 & (GTG)5 & $180-1200$ & 10 & 10 & 0 & 0 & 20 \\
\hline & SPS8 & $(\mathrm{GGA}) 4$ & $300-885$ & 7 & 3 & 4 & 4 & 6.666 \\
\hline & SPS9 & (CAA) 5 & $550-1600$ & 5 & 4 & 1 & 0 & 9 \\
\hline \multirow{2}{*}{\multicolumn{2}{|c|}{$\begin{array}{l}\text { Total } \\
\text { Grand total }\end{array}$}} & & & 78 & 69 & 9 & 6 & 6 \\
\hline & & & & 140 & 131 & 9 & 6 & \\
\hline
\end{tabular}

\section{ISSR analysis}

9 ISSR primers resulted in the amplification of 78 fragments. The primer (GAC) 5 produced the maximum number of bands (13), while primer (CAA) 5 produced a minimum number of bands (5). From 78 bands amplified, 69 bands were monomorphic, 3 were polymorphic and only 6 were found to be unique bands. The bands were amplified in the range of $180-2000 \mathrm{bp}$. Among these ISSR primers, 
maximum resolving power (26) was obtained in (GAC)5 primer and minimum Rp (6.666) was in (CAA) 5 (table 1, fig. 1c, d).

\section{Analysis of data of combined markers}

For assessment of genetic similarity among 4 populations of $H$. coronarium, two types of marker combination (RAPD and ISSR) was taken. A total of 140 bands were amplified with all the marker out of which 131 were monomorphic, 3 were polymorphic and rest 6 were unique bands (table 1). All the samples were correlated with each other with an average similarity of 0.978 which ranged 0.957 to
1.000. The dendrogram constructed using Jaccard's similarity coefficient, separated the 4 populations into two major clusters, one with 11 samples another with rest 1 sample at similarity coefficient of 0.96 (fig. 2). Cluster II included one replicate of Malkangiri population while cluster I included rest of the populations.

Cluster I further divided into two subgroups which include three replicates of Angul and Khurda populations, two replicates each of Malkangiri and Phulabani populations while subcluster B includes only one replicate of Phulabani population.

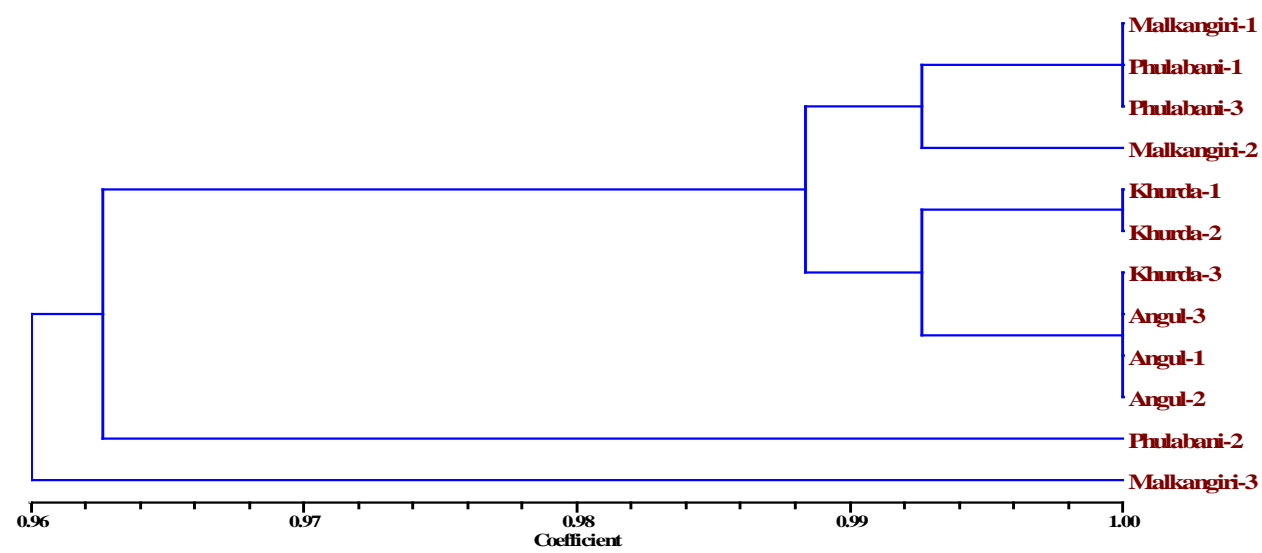

Fig. 2: Dendrogram showing genomic relationship within 4 populations in $H$. coronarium as revealed from combined RAPD and ISSR analysis

\section{DISCUSSION}

Accurate identification and characterization of different germplasm resources is important for species identification, cultivar development, certification and breeder's right's protection $[40,41]$. With the advent of molecular biology techniques, DNA-based markers very efficiently augment morphological, cytological, and biochemical characters in germplasm characterization, varietal identification, clonal fidelity testing, assessment of genetic diversity, validation of genetic relationship, phylogenetic and evolutionary studies, marker-assisted selection and gene tagging. Owing to plasticity, ubiquity and stability, DNA markers are easier, efficient, and less time consuming especially in perennials where morphological markers are few. In recent times there is an increased emphasis in molecular markers for identification and characterization of the genotypes, genetic fingerprinting in identification and cloning of important genes, marker-assisted selection and in the understanding of interrelationships at the molecular level. The polymerase chain reaction (PCR), based technologies such as RAPD, ISSR, AFLP and microsatellites, are widely appreciated for its genetic integrity as well as cost effectiveness and simplicity. Although work on morphological characterization of Zingiberaceous species has been attempted, its molecular characterization is still in a nascent stage except for some genetic fidelity studies of micro-propagated plants and isozyme-based characterization $[15,16,42]$.

The origin and relationships of Alpinia galanga based on its molecular data were studied by [43]. RAPD markers were used to assess the level of genetic diversity in 71 Alpinia accessions (31 cultivated and 6 wild) collected from different areas of Thailand [44]. Their UPGMA cluster analysis of genetic similarity also separated the accessions into 5 major clusters. Molecular genetic fingerprints of nine Curcuma species from Northeast India using PCR-based markers were studied by [45]. A phylogenetic analysis of the tribe Zingiberaceae was performed by [46] using nuclear ribosomal DNA (ITS1, 5.8S, and ITS2) and chloroplast DNA (trnL [UAA] 5 exon to trnF [GAA]). The study indicated that tribe Zingiberaceae is monophyletic with two major clades, the Curcuma clade, and the Hedychium clade. The general Boesenbergia and Curcuma are apparently not monophyletic. The populations having similarity within each other is grouped under the same cluster which is similar with the report of [47]. In his study of genetic diversity among ginger germplasm collected from gene bank, local farm and market collection and found one accession from Bangladesh to be identical with one accession from Pakistan and two accessions each from Japan and China were also similar to each other. He explained the occurrence of similarity could be the presence of the same genotype in the market in different countries which matches with our result and with our supposition as presented above. Some other studies like gas chromatography-mass spectrometry (GC-MS) and highperformance thin layer chromatography (HPTLC) analysis could be done for identification of elite cultivars $[48,49]$.

\section{CONCLUSION}

It gives a good control on the preservation of genetic resources and facilitates international exchanges of healthy plant material. In the present report, two PCR-based molecular markers like RAPD and ISSR has been used to characterise different populations of Zingiberaceae. Basing upon their genetic similarity dendrograms were constructed for each species which confirm their genetic relationship by dividing the populations into many clusters and subclusters. Samples present in single clusters represent their closeness with each other.

Hence it could be concluded that there must be an intraspecific polymorphism in between the populations. At the same time, less number of samples analysed need a further classification. The potential of the present work will be realised to the fullest extent for the establishment of relationship within a population of Zingiberaceae.

\section{ACKNOWLEDGEMENT}

The authors are grateful to Prof (Dr.) S. C. Si, Dean, Centre of Biotechnology and Prof (Dr.) M. R. Nayak, President, Siksha O Anusandhan University for providing facilities and encouraging throughout.

\section{CONFLICT OF INTERESTS}

Declared none

\section{REFERENCES}

1. Lim SH, Teng P, Peng C, Lee YH, Goh C. RAPD analysis of some species in the Genus Vanda (Orchidaceae). Ann Bot 1999;83:193-6. 
2. Landry BS, Li R, Gheung WY, Grangor RL. Phylogenic analysis of 25 apple stocks using RAPD markers and tactical gene tagging. Theor Appl Genet 1994;89:847-52.

3. Vierling VA, Nguyen HT. Use of RAPD markers to determine the genetic diversity of diploid, wheat genotypes. Theor Appl Genet 1992;84:835-8.

4. Parani M, Anand A, Parida A. Application of RAPD fingerprinting in the selection of micro-propagated plants of Piper longum for conservation. Curr Sci 1997;73:81-2.

5. Cao W, Soles G, Huel P, Chibbar RN. The use of RAPD analysis to classify Triticum accessions. Theor Appl Genet 1999;98:602-7.

6. Khan SA, Hussain D, Askari E, Stewart J. Molecular phylogeny of Gossypium species by DNA fingerprinting. Theor Appl Genet 2000;101:931-8.

7. Qian WGS, Hong DY. Genetic variation within and among populations of a wild rice Oryza granulata from China detected by RAPD and ISSR markers. Theor Appl Genet 2001;102:440-9.

8. Fernandez ME, Figueiras AM, Benito C. The use of ISSR and RAPD markers for detecting DNA polymorphism, genotype identification and genetic diversity among barley cultivars with known origin. Theor Appl Genet 2002;104:845-51.

9. Zucchi MI, Arizono H, Morais VI, Fungaro MHP, Vieira MLC. Genetic instability of sugarcane plants derived from meristem cultures. Genet Mol Biol 2002;25:91-6.

10. Nayak S, Debata BK, Srivastava VK, Sangwan NS. Evaluation of agronomically useful somaclonal variants in jamrosa (a hybrid Cymbopogon) and detection of genetic changes through RAPD. Plant Sci 2003;164:1029-35.

11. Singh M, Saroop J, Dhiman B. Detection of intra-clonal genetic variability in vegetatively propagated tea using RAPD markers. Biol Plant 2004;48:113-5.

12. Hofmann NE, Raja A, Nelson RL, Korban SS. Mutagenesis of embryogenic cultures of soybean and detecting polymorphism using RAPD markers. Biol Plant 2004;48:173-7.

13. Venkatachalam L, Sreedhar RV, Bhagyalakshmi N. The use of a genetic marker for detecting DNA polymorphism, genotype identification and phylogenetic relationship among banana cultivars. Mol Phylogenet Evol 2008;47:974-85.

14. Lu X, Liu L, Gong Y, Song X, Zhu X. Cultivar identification and genetic diversity analysis of Broccoli and its related species with RAPD and ISSR markers. Sci Hort 2009;122:645-8.

15. Wahyuni S, Xu DH, Bermawie N, Tsunematsu H, Ban T. Genetic relationships among ginger accessions based on AFLP markers. Jurnal Bioteknol Pertanian 2003;8:60-8.

16. Nayak S, Naik PK, Acharya LK, Mukherjee AK, Panda PC, Das P. Assessment of genetic diversity among 16 promising cultivars of ginger using cytological and molecular markers. $\mathrm{Z}$ Naturforsch 2005;60:485-92.

17. Hansen M, Kraft T, Christiansson M, Nilsson NO. Evolution of AFLP in Beta. Theor Appl Genet 1999;98:845-52.

18. Lakshmi M, Paroni M, Ram N, Panda A. Molecular phylogeny of mangrove intraspecific variation in mangroves species, Excoecaria agallocha L (Euphorbiaceae) Genome 2000;43:110-5.

19. Divakaran M, Sajina A, Babu KN, Ravindran PN. Ovule culture of vanilla and its potential in crop improvement. Proceedings of the National Seminar on Biotechnology of Spices and Aromatic Plants, April 24-25, Calicut, Kerala, India; 1996. p. 112-8.

20. Damiano C, Monticelli S, Frattarelli A, Nicolini S, Corazza L, Altman A, Ziv M. Somaclonal variability and in vitro regeneration of strawberry. Acta Hortic 1997;447:87-93.

21. Babu TD, Nazeem PA, Kesavachandran R, Achuthan CR, Girija D, Sureshkumar P, et al. Detection of genetic diversity in Piper species using RAPD and AFLP markers. In: New perspectives in spices, medicinal and aromatic plants. Korikanthimath VS, Zachariah TJ, Babu KN, Bhai RS, Kandiannan K. Eds. Indian Society for Spices, Calicut, Kerala, India; 2003. p. 2-8.

22. Alagammal M, Tresina PS, Mohan VR. GC-MS determination of bioactive components of Polygala javana dc. Int J Curr Pharm Res 2012;4:42-4.

23. Virani P, Sojitra R, Raj H, Jain V. Chromatographic method for irbesartan and its combination with another drug. J Crit Rev 2015;2:7-11.

24. Johnson GK, Varma SR, Ganga G, Renuka M, Shiju KC. ISSR-PCR, a potential tool for genetic diversity analysis in spices.
Proceedings of National Seminar on New Perspectives in Spices, Medicinal and Aromatic Plants, Nov. 27-29, Goa, India; 2003. p. 23-6.

25. Gantait S, Mandal N, Bhattacharyya S, Das PK. Determination of genetic integrity in long-term micro propagated plantlets of Allium ampeloprasum L. using ISSR markers. Biotechnology 2010;9:218-23.

26. Sreedhar RV, Venkatachalam L, Roohie K, Bhagyalakshmi N. Genetic fidelity of long-term micro propagated shoot cultures of vanilla (Vanilla planifolia Andrews) as assessed by molecular markers. Biotechnol J 2007;2:1007-13.

27. Verma PC, Chakrabarty D, Jena SN, Mishra DK, Singh SK, Sawant SV, et al. The extent of genetic diversity among Vanilla species: comparative results for RAPD and ISSR. Ind Crops Prod 2009;29:581-9.

28. Debnath SC, Khanizadeh S, Jamieson AR, Kempler C. Intersimple sequence repeat (ISSR) markers to assess genetic diversity and relatedness within strawberry genotypes. Can J Plant Sci 2008;88:313-22.

29. Doyle JJ, Doyle JL. A rapid DNA isolation procedure for small quantities of fresh leaf tissue. Phytochem Bull 1990;19:11-5.

30. Sambrook J, Fritsch EF, Maniatis T. Molecular cloning: a laboratory manual: $2^{\text {nd }}$ Ed. 1989;3:18-47.

31. Williams JGK, Kubelik AR, Liva KJ, Rafalski JA, Tingey SV. DNA polymorphisms amplified by arbitrary primers are useful as genetic markers. Nucleic Acids Res 1990;18:6531-5.

32. Zeitkiewicz E, Rafalski A, Labuda D. Genome fingerprinting by simple sequence repeat (SSR)-anchored PCR amplification. Genomics 1994;20:176-83.

33. Gherardi M, Mangin B, Goffinet B, Bonnet D, Huguet T. A method to measure genetic distance between allogamous populations of alfalfa (Medicago sativa) using RAPD molecular markers. Theor Appl Genet 1988;96:406-12.

34. Prevost A, Wilkins MJ. A new system for comparing PCR primers applied to ISSR fingerprinting of potato cultivars. Theor Appl Genet 1999;98:661-8.

35. Smith JSC, Chin ECL, Shu H, Smith OS, Wall SJ, Senior ML, et al. An evaluation of the utility of SSR loci as molecular markers in maize (Zea mays L.): comparison of data from RFLPs and pedigree. Theor Appl Genet 1997;95:163-73.

36. Ghislain M, Zhang D, Fazardo D, Huamann Z, Hismans RH. Marker assisted sampling of the cultivated andean potato Solanum 122 fureja collection using RAPD markers. Genet Resour Crop Evol 1999;46:547-55.

37. Jaccard P. Nouvelles recherche sur Ia distribution florale. Bull Soc Vaudense Sci Naturelles 1908;44:223-70.

38. Sneath PHA, Sokal RR. Numerical taxonomy, Freeman, San Francisco, California; 1973. p. 573.

39. Rohlf FJ. NTSYS-pc numerical taxonomy and multivariate analysis system. Version 2.02e. Exeter Software, Setauket, New York; 1997.

40. Hale AL, Farnham MW, Menz MA. The effectiveness of PCRbased markers for differentiating elite broccoli inbreds. J Am Soc Hortic Sci 2006;131:418-23.

41. Sharma S, Saraogi GK, Kumar V. Development of spectrophotometric methods for simultaneous determination of artesunate and curcumin in a liposomal formulation. Int J Appl Pharm 2015;7:18-21.

42. Mandal AB, Thomas VA, Elanchezhian R. RAPD pattern of Costus spaciosus Koen ex. Retz., an important medicinal plant from the Andaman and Nicober Islands. Curr Sci 2007;93:369-73.

43. Rangsiruji A, Newman MF, Cronk QCK. A study of the infrageneric classification of Alpinia (Zingiberaceae) based on the ITS region of nuclear rDNA and the trnl-F spacer of chloroplast DNA. In: KL Wilson, Morrison DA. Eds. Monocotssystematics and evolution, CSIRO Publishing, Collingwood, Australia; 2000. p. 695-709.

44. Saritnum 0, Sruamsiri P. Random amplified polymorphic DNA analysis of galanga (Alpinia spp.) accessions. CMU J 2003;2:159-64.

45. Das A, Kesari V, Satyanarayana VM, Parida A, Rangan L. Genetic relationship of Curcuma species from northeast India using PCR-based markers. Mol Biotechnol 2011;49:65-76. 
46. Ngamriabsakul C, Newman MF, Cronk QCB. The phylogeny of tribe zingibereae (Zingiberaceae) based on ITS (nrDNA) and trnL-F (cpDNA) sequences. Edinburgh J Bot 2003;60:483-507.

47. Jatoi SA. Diversity on Zingiberaceae genetic resources with special reference to Myanmar. University of Tsukuba, Tsukuba, Japan; 2008.

48. Amutha ID, Arumugam KM. Gas chromatography-mass spectrometry analysis of photo components in the ethanolic extract from the whole plant of Lactuca runcinata dc. Asian J Pharm Clin Res 2015;8:202-6.
49. Mercy LS, Ilavarasan R, Gnanamani A. Physico-chemical, phytochemical and hptlc analysis of the whole plant of Orthosiphon thymiflorus (roth.) sleesen. Asian J Pharm Clin Res 2015;8:181-4.

\section{How to cite this article}

- Reena Parida, Sujata Mohanty, Sanghamitra Nayak. Molecular characterization of endangered medicinal plant species Hedychium coronarium from eastern India. Int J Pharm Pharm Sci 2017;9(1):173-178. 